\title{
Online Labour Activism In Turkey: An Analysis Of The Web-Based Activism Capacities Of The Alternative Media And The Labour Unions
}

\author{
Türkiye'de Çevrimiçi Emek Aktivizmi: Işçi Sendikalarinin Ve Alternatif Medyanin Web \\ Tabanli Aktivizm Kapasitelerinin Analizi
}

\author{
Assoc. Prof. Dr. A. Fulya ŞEN ${ }^{1}$ \\ Firat University, Faculty of Communication, Elazig
}

\begin{abstract}
The Internet and its activism power have been discussed in recent years. This study deals with the roles of class-based alternative media and the websites of two labour unions in providing a democratic platform and their potential for strengthening of the labour union movements and examines "Sendika.Org" as the voice of labour movement and the websites of two important labour unions, Confederation of Public Workers' Unions (KESK) and Confederation of Revolutionary Workers' Unions (DiSK), to reveal their potentials in triggering the labour movement and class-based discussions in society. In this context, this study focuses on the nature of social networking activism and the potential of the alternative media in the context of theoretical framework of the public sphere and online activism and it discusses the creative potential of the Internet as a public sphere. It also attempts to explain how these websites present themselves to the public and mobilise citizens and activists. Also, it analyses the websites' potential of political resistance towards the social inequalities and the class-based issues by using the content analysis method constituted by certain categories such as information provision, networking, participation, campaigning, and delivery. The aim of this study is to reveal to what extent the activists use these websites as means for mobilisation and how alternative media and the websites of the labour unions create an alternative public sphere among the online audience and how they encourage the activists to participate in the online and offline actions.
\end{abstract}

Keywords: Online activism, Internet, social media, public sphere, labour unions, DISK, KESK, sendika.org, class-based activism

Özet: İnternetin aktivizm gücü son yıllarda tartışımaktadır. Bu çalışma, sınıf temelli alternatif medyanın ve iki işçi sendikasının web sitelerinin demokratik bir platform sağlama ve bunların sendikal hareketleri güçlendirme potansiyellerini ele almakta ve işçi hareketinin sesi olanrak "Sendika.Org" adlı alternative haber sitesini ve iki önemli işçi sendikası olan Kamu İş̧ileri Sendikaları Konfederasyonu (KESK) ile Devrimci İşçi Sendikaları Konfederasyonu (DiSK)'nun toplumda sınıf temelli tartışmalara ve emek hareketine zemin hazırlama potansiyellerini incelemektedir. Çalışma, kamusal alan ve çevrimiçi eylemcilik teorileri bağlamında sosyal ağ aktivizminin doğasına ve alternatif medyanın potansiyeline odaklanmakta ve internetin bir aktivist için kamusal alan olarak yaratıcı potansiyelini tartışmakta; ayrıca, bu web sitelerinin kendilerini halka nasıl tanıttığını,

\footnotetext{
${ }^{1}$ fulyasen@firat.edu.tr
} 
yurttaşları ve aktivistleri nasıl harekete geçirdiğini açıklamaya çalışmakta; web sitelerinin sosyal eşitsizliklere ve sınıf temelli meselelere yönelik siyasi direnme potansiyelini, bilgi sağlama, ağ oluşturma, katılım, kampanya oluşturma ve dağıtım gibi belirli kategorilerden oluşan içerik analizi yöntemini kullanarak analiz etmektedir. Bu çalışmanın amacı, aktivistlerin bu web sitelerini mobilizasyon araçları olarak ne ölçüde kullandıklarını, alternatif medyanın ve işçi sendikalarının web sitelerinin çevrimiçi izleyici arasında nasıl bir alternatif bir kamusal alan yarattığını ve aktivistleri çevrimiçi ve çevrimdışı eylemlere katılmak için nasıl teşvik ettiğini ortaya koymaktır.

Anahtar sözcükler: Çevrimiçi aktivizm, internet, sosyal medya, kamusal alan, sendikalar, DiSK, KESK, sendika.org, sınıf temelli aktivizm

\section{Introduction}

The media has an important place in the history of labour movements in providing visibility for resistance. However, as the media structure has changed and become more complex and differentiated, it creates both new opportunities and challenges. Today, what extent that the labour movement can take advantage of media platforms is a key point to understand the decline of labour movements and labour unionism. Historically, labour unions have sought to develop their media and a working class culture and faced with many challenges for representation in the capitalist media. The main reason of this is the spread of neoliberalism as the primary ideological outlook of the world's political and economic elites. This approach is hostile to the idea of an independent labour movement, so the labour unions and the labour movement are not represented in a way of sufficient and positive in media (Dencik and Wilkin, 2015). The trends of privatisation, conglomeration, trans-nationalization and deregulation have amplified and broadened the economic logic of media operations. The free-market approach excludes broad social interests from participating in the control of the mainstream media, and it leads to concentration of media ownership and promotes cultural uniformity. An essential requirement of a democratic media system is to represent the interests of different social groups in society.

The history of the labour movement and its relation to the mainstream media has long been viewed as one of antagonism and misrepresentation. Given the oppositional role of capital and the state, the labour movement has often played to disseminate socialist-inspired ideas about a society built on principles of mutual aid, cooperation, self-help and direct action. Thus, it is exposed to be either destroyed, curbed or co-opted by the main political and economic institutions. The control of language and the representations of events through media is also an attempt to control the way in which people thought about the social world. With the emergence of elite-led neoliberal political and economic movements in the 1970s, the US model of commercial profit-seeking media has now become the global norm displacing public service models (Dencik and Wilkin, 2015, pp.11-14).

The labour movement is benefited from advantages of new media and uses new Internet-based platforms to promote and organize their activities, so a counter-media is crucial for the labour movement. The potential of Internet for activism has been discussed in media studies. Many researchers have focused on democratic aspects of the Internet as a public sphere providing a democratic platform for citizens. This feature can be used to mobilise people or to deliver data on a mass scale. Thus, the networks have been able to internationalise easily, and experimentation has flourished due to the lack of centralized control (see in Tatarchevskiy, 2011; Feenberg, 2014). The Internet has drastically altered the cost structure of participation, and has also increased the spectrum of possible political activities. Via the Internet, a citizen can forward emails with political content and try to influence government decisions through comments posted on websites. The existence of new types of action can only serve to increase the total level of political participation. Impacts on levels of participation depend on the extent to which the new channels are used (Anduiza et al., 2009).

There is a widespread perception that the Internet is an inherently democratic technology. 
Accordingly, the Internet is a vehicle for extending democracy in social and cultural life. The Internet enables new forms of political activism and enhances democracy by engaging with previously marginalized communities. The ecology and peace movements make extensive use of the Internet as a vehicle both for disseminating information and organizing activists. The other contention is that the Internet will transform and enlarge the notion of democracy. In this view, the public sphere is expanded and takes on multiple forms that open up new places from which to speak. The public sphere is a space for the democratic exchange of ideas (Barker, 2012: 364-371). Kavada (2005) points out that the Internet has been hailed, as the medium to breath new life into civil society and the public sphere, and its political potential have been the source of optimism. Optimists hope that the Internet will increase the pluralism of voices within the public sphere by providing a space for non-mainstream and fringe organizations to publish their opinions. Its networking capabilities can also be used to strengthen the bonds between different organizations, fostering solidarity and a sense of mutual support. Furthermore, by encouraging participation and online deliberation, the Internet can deepen the involvement of the public with civil society organizations. The optimism around the Internet and its political potential are linked to a belief in its publication and networking capabilities.

Van Laer and Van Aelst (2010) have emphasised some limitations of Internet-based activities. For instance, a digital divide referring to the inequality in internet access and the weakness of the internet in creating strong ties. The internet is unable to create the necessary trust and strong ties that are required to build a sustainable network of activists. These restrictions make clear that even a wide digital action repertoire will not, and probably never will, be able to replace traditional forms of activism and face-to-face communication. Despite some limitations, the Internet enables social movements to follow that transition and operate more globally.

The character of the Internet as a system for the cooperative production of knowledge, the global sharing of knowledge, real-time and multi-communication, allow the emergence and permanent reproduction of social systems of global protest. By Internet communication, protestors produce shared meanings that constitute collective identities and practices. the Web form of protest is not a result of the Internet, rather, protest movements use network technologies because they help them in advancing networked forms of protest. Protest movements need public visibility; they are unimportant if they are not perceived and get no attention. Internet is a global space that is used by protest movements in order to be perceived by the global political public and to build a counter public, an alternative public sphere (Fuchs, 2008).

Bohman (2010) discusses how the Internet and other forms of electronic communication might contribute to a new kind of public sphere, and potentially a new form of democracy. A public sphere always requires the expansion of dialogue beyond face-to-face encounters and is, therefore, always dependent on some form of communication technology. According to Bohman (2010), current Internet publics are 'weak' publics because of negative effects or consequences, such as their disaggregative character or their anonymity. If the active public is wanted, it should be made to participate in a larger framework together with institutionalized decision-making procedures, and the dialogical character of the traditional public sphere extended in a cosmopolitan way. In comparison with the past, the epistemic requirements for participating in large scale and potentially transnational communication have lessened, to such an extent that it is widely available beyond elites in wealthy societies. Deliberative publics can be strong publics distributively, capable of exerting political influence in real decision-making processes under certain institutional conditions.

The Internet represents a discursive arena that is home to citizens' debate, deliberation, agreement and action. However, critical thoughts also exist about political participation through Internet. Dahlgren (2004) points out that social medias do not automatically result in politics, protest and political participation, but have the potential to foster political struggles and engagement. Being in a political discussion online is an important 
step but would not automatically constitute political participation. Dahlgren (2004) states that "if we understand participation as deriving from a sense of urgency embedded in our subjective reality, in our identity, social media on their own will not do much to promote it. Rather, for those without an already existing political sense of self, the discursive contribution of social media will tend to deflect political participation" (p.200).

Dahlberg (2001, p.615) mentions that "three prominent 'camps' have emerged within Internet democracy rhetoric and practice, each drawing upon different models of democracy: communitarian, liberal individualist and deliberative." Dahlberg (2001) highlights the lack of online deliberation within the framework of the set of requirements of Habermas' theory, such as discursive inclusion and equality, sincerity, ideal role taking, reflexivity, and autonomy from state and economic power. Moreover, the lack of equality within the online public sphere will remain as long as there are inequalities in the distribution of social resources, including the issues of digital infrastructures and the cost of the Internet, computing skills, cultural expectations, free time and community support.

Since alternative media is the Internet-based, it has importance for online labour activism. The new social movements have emerged as a direct result of Internet technologies. Activists often utilise the web technologies to recruit, strategize, and create change, and some activism fixes on the politics of the Net itself. Many researchers have revealed that the Internet promotes social movements, but also makes possible for an alternative media source devoted to social change. Further, the Seattle organisers' use of the Internet and its multimedia capacities has shown that corporate-controlled media was bypassed (see in McCaughey and Ayers, 2003). The Zapatista uprising, which started in 1994, and the 'Battle of Seattle' in 1999 is used two iconic examples to illustrate how the Internet shapes social movements and the tactics they use to pursue their claims. Moreover, Barack Obama's campaign in 2008 built upon this basic strategy, incorporating social networking, voter outreach, volunteer opportunities, and video clips on its website. By inspiring from this model, Internet-based politics has encouraged the online political activist organisation.

Alternative media is often referred to as a "radical media" or "citizens' media" comprising a vast range of media production activities embedded in the everyday struggle by communities and individuals (Couldry \& Curran 2003, p.7). The contribution of media activism to media democracy is to develop the dissident thoughts that go beyond established politics. Alternative media aims to create an environment that has public liability and to produce an independent content exclusive of the ownership and control relationships. For this reason, alternative journalism is crucial to inter-nationalizing the values of democracy. Harlow \& Harp (2012, p.199) note that 'social movements and activists often create their own media in order to counter the hegemonic messages, misinformation, and negative portrayals of activism typical in the mainstream press.' The terms "participatory," "alternative" and "community media" are used to refer to more deliberative and critical communicative platforms which are against mass media and traditional elites. Alternative and participatory media have a great importance in terms of being a ground for online activism. These medias allow environmental groups to direct how their causes and actions will be represented and to distribute their information quickly to the audience. From this point of view, one can examine where activists perform their goals and how they create participative practices.

Internet technologies provide overcoming the participation obstacles which stem from time constraints, lack of skills, and low income. Online movements let people choose when to click. Successful online groups use the Internet communications and networking to teach supporters new political skills. Virtual petitions, forums to debate issues, and the use of social media and email constitute the ways in which today's political activists try to recruit people for meetings and protests and to engage citizens and influence the political process. Social movements across the political spectrum use new technologies to effect change and 
influence party politics (Rohlinger et al., 2014). The Internet plays a crucial role in transnational protest allowing for immediate communication across the globe. The Internet represents a new technology that has the potential to communicate and mobilize political agency and as a consequence reinvent activism (Fenton, 2007). The nature of digital activism, the relationship between online and offline mobilisation and organisation, the use of social media platforms for resisting and challenging forms of domination and institutions of power compose some key points of activism process. Digital and social media create the platforms to share information and news about workers' struggles and union campaigns that are neglected in traditional mainstream media and puts pressure on corporations and political elites (Dencik and Wilkin, 2015, p.82).

In this study, I have examined "The Sendika.Org" as the voice of labour movement and the websites of two important labour unions in Turkey -The Confederation of Public Employees' Trade Unions (KESK) and Confederation of Revolutionary Workers' Unions (DiSK)- to reveal their potentials in triggering the labour movement and class-based discussions in the society. I have also focused on how class-based civil society organisations mobilise their members ultimately for online and offline activism and the potential of the alternative media in online activism practices by following theories of the public sphere and online activism. In this context, I have discussed the creative potential of the Internet as a public sphere and analysed "The website of Sendika.Org" and the other websites to understand how they present themselves to the public and mobilise the citizens and activists.

The research questions are as follows:

RQ 1: Which issues are emphasised?

RQ 2: What role does the Website play in motivating people to action?

RQ 3: How has the Internet been used as a means for action on its own?

I have analysed the sample Websites in terms of creating a political resistance which concentrates on the social inequalities and workers' rights and aimed to reveal how alternative media and the websites of labour unions serve to create an alternative public sphere among the online audience and how they encourage activists participating online also to participate offline. I have also discussed the activism-based potential of the new communication technologies in creating a dissident resistance.

\section{Literature Review}

Kende (2016, p.400) defines the activism as all about changing or preserving the social order and the work of activists, which will almost inevitably be contrary to the perceived political or economic interests of powerful elements of the society. Vegh (2003, pp.71-84) also defines online activism as a politically motivated movement relying on the Internet. Activists take advantage of the technologies and techniques offered by the Internet to achieve their goals and divides online activism into three main categories: Awareness/advocacy, organisation/mobilisation, and action/reaction. Firstly, public awareness is achieved by accessing information. The Internet serves alternative news and the news focusing on issues not reported or misreported in the mainstream media are provided by independent organisations. The forms of obtaining information include visiting relevant websites or participating in different types of email distribution lists. The second step of online activism is the organization or mobilisation. The Internet can be used to call for offline action or an online action. The most efficient way is to set up a Website providing information. The third step also contains the proactive and aggressive usage of the Internet. The first well-known example is the pro-Zapatista movement in support of the struggle of the indigenous people of Chiapas against the oppression of the Mexican government, and the Internet has provided an advanced communication space. A group of activists and artists engaged in practising what they call "electronic civil disobedience." Similarly, the global resistance took place against the World Trade Organization. The Internet was used to launch an online attack against the website of WTO. The Internet became the battlefield upon which to resist globalism and cultural hegemony. 
Milan and Hintz $(2013$, p.8) point out decentralised cyber activist groups are rarely represented in the discussion and decision-making processes of governance compared to nongovernmental organisations (NGOs) serving as proxies for the inclusion of the civil society's voice in policy debate. Researchers also argue that technology activism highlights current forms of interaction and association that differ from established modes of formal organisation and representation and they state that activist groups provide the digital backbone of social movements, enabling protest coordination, and campaigning. Zhang (2014) has examined activism that has emerged in online communities in China. This ethnographic study of two web-based backpacking communities showed that citizens and activists use the Internet mainly for forming communities, sharing information, instilling democratic values and solving immediate social problems. According to Zhang (2014, p. 292), the web-mediated collective practices have demonstrated new tactics and goals of online activism. Members of online communities aim to raise public awareness, disseminate knowledge, and mobilize collective action to solve immediate social problems. This new form of online activism no longer relies on centralised leadership, no longer mobilises large-scale mass demonstrations or calls for radical political change; instead, it emphasises collaboration, civic participation, and social and cultural change.

The network formation of the Internet promotes communication between people. Notably, Web 2.0 sites represent a dynamic form of participating in social and political issues. However, the new media technologies do not mean a democratic public sphere. According to Roberts (2014, pp.2-8), digital technology is also employed to control and govern specific populations in line with the marketization of society. Accordingly, the state acts through specific political and social projects in civil society and the public sphere to gain support from some sections of society. The states and another political mechanism can implement a neoliberal agenda through digital surveillance systems. While deliberative ideals and new media appear as exciting opportunities to establish new democratic capabilities in society, the state projects attempt to govern and regulate specific contradictions in society, but will do so in part through discourses of enhancing democracy and through new technologies. Roberts (2014) also emphasises one another concern that the changing nature of the public sphere. Neoliberalism radically modifies the nature of publicness in civil society. On the other hand, common beliefs and dialogue have an antagonistic potential because the opportunity to enter into public dialogue about specific contradictions and their social problems is a very real possibility. Therefore, the alternative and critical public spheres emerge despite dominant power relations.

Activist media encourages readers to get actively involved in social change. When an activist media advocates left-wing or anarchist politics, some readers or viewers would expect them not to be produced primarily to make a profit for their publishers, and regard them as relying on participation and readership by average people rather than highly educated elites. Although they are imperfect, electronic medias can be useful for alternative media practitioners and activists. They provide ways of reaching potentially large audiences which are much less expensive than any other method, and can provide some types of information that traditional media cannot (Waltz, 2005). The participatory and interactive nature of the Internet, such as email lists, newsgroups or chatrooms, can be used to foster solidarity within the organisation and deepen the public's involvement. Civic organisations can further use the Internet to mobilise support and generate resources more cheaply and efficiently. the Internet has created opportunities for innovative campaigning and activism and constitutes a space for organisations to extend their existing repertoires of action or create new ones (Kavada, 2005).

The growth of divisions between different sections of the workforce both in developed capitalist economies - between permanent and temporary workers; between employed and unemployed; between nonmigrants and immigrants - and between some workers in developed and those in developing economies have undermined the power of the organised labour. The trade union movement has a long-standing tradition of international solidarity. Trade unions may understand and commit to international unionism in many ways 
through staffing, financial resources and philosophical commitment. There is an enormous chasm between the operation of global trade and production and the organization of global labour. The roots of the crisis of trade unionism partly lies in the transformation from a national-industrializing capitalism into a globalized networked capitalism in which production and services, work for capital and the working classes are undergoing de- and reconstruction with unions being reduced in size and politically marginalized (Downey and Fenton, 2007, pp. 653-654).

Sawchuk (2003) argues that there is strong evidence to suggest that online learning can be a valuable addition to the education capacity of the labour movement and that the potential of computer technologies provides aid in the activity and development of the labour movement. As the labour movement depends on the collective actions and the participation, it is important to understand how activists' broader life and labour movement activity affected their participation and informal learning online. In Canada, a union-based computer communications, and later online learning are used in labour education having a rooted past. Especially, "Informal Learning Practices within Union-based Tele-learning" project is one of the learning practices amongst Canadian trade union activists surrounding the trial use of new online learning technologies as part of the labour education and training activities. According to Sawchuk $(2003$, p.180), there is strong evidence to suggest that online learning can be a valuable addition to the education/communication capacity of the labour movement. Furthermore, there were equally strong grounds for concluding that an important part of this positive contribution revolves around recognition of informal learning, the tacit dimensions of participation, the broader context of participants' lives, and the linkages between the online and the offline world. That is, online activity can be transferred to the offline world.

Privatisation has a fragmented collective organisation in the public sector reinforcing a more general decline in collective bargaining. In global capitalism period, it is seen the collapse of collective bargaining in the private sector and its attenuation in the public sector through privatisation. The privatisation of services, often based upon an ethnic division of labour underpinned by state immigration policies, limits the development of structures of engagement for migrant workers. Materially, the relationships between work and class, race, gender and ethnicity are explicit and defined by the wider relations of a capitalist system. The articulation of these material relationships is dependent upon political organisation and language, which may crystallise or privilege one particular identity at the expense of others. In the 1980s it was commonly argued that shifts in values and lifestyles supposedly encourage individualism and privatism leading to a decline in class-based politics. The class-consciousness and class awareness no longer exist (Moore, 2011).

The economic system of Turkey was based on a planned development model and the importsubstitution industrialization of the pre-1970 era. However, in line with the neo-liberalization efforts in many other countries in the late 1970s, Turkey liberalized the market mechanism to converge the national economy with global capitalism. This structural change came with the January 24, 1980 measures, which were reinforced by the September 12, 1980 military coup. In 1983 the liberal Özal government came to power and obtained the support of the International Monetary Fund (IMF) and the United States (Inal and Akkaymak (2012). In Turkey, the inclusionary developmental state of the 1960s-70s transformed into the institutionalised of a new form of state called "the neoliberal exclusionary state" in the 1980s. The pivotal aspect of the neoliberal exclusionary state was the exclusion of organized labour from the political process and its disciplining in the economic sphere. The balance of power was shifted in favour of capital and Turkish economy was reconstructed towards an open-market and export-oriented model. In the 1980s, centrally organised interventionism was applied against organised labour to discipline and weaken it. Also, the state actively intervened in labour-capital relations to control, weaken, or dismantle institutions, specifically labour unions, strike activity, and collective bargaining (Önder, 2016). 
Dogan (2010, pp.2-4) argued that the Özal administration of the 1980s targeted the moral economy of the public enterprise workers, and hence the very foundation of the Turkish-organized labour movement with its neoliberal emphasis on replacing the entrenched developmental and populist mode of operation in state economic enterprises with market rationality and profit-maximizing behaviour. Such policies are not unique to Turkey; indeed they were the basic tenets of structural adjustment programs that international financial organisations promoted in indebted third world countries. The transformation that entered the political agenda in the aftermath of the coup d'état in 1980 threatened the raison d'être of public enterprises as economic institutions with developmental rather than profit-maximizing objectives. The crisis of import substitution made the balance of payments problems insurmountable; thus the problems related to budgetary deficits worsened. When international financial institutions imposed austerity measures on the borrowing countries, the public sector could no longer produce losses for the sake of promoting economic and social development. After the 1980 coup, the right to unionise and strike was severely restricted.

Trade unions' membership numbers have dropped dramatically in the rich world over the last three decades. From a peak of $20 \mathrm{~m}$ members in 1979, they fell to $14.5 \mathrm{~m}$ in 2013 in America and from $12 \mathrm{~m}$ to $6.5 \mathrm{~m}$ in Britain, according to the OECD, a club of mostly rich countries. European countries, including Germany and France, have also seen huge drops in membership. It has become harder for unions to regulate the work due to the globalisation and the rise of a more flexible service (Economist, 2015). Similarly, according to January 2016 data from the Ministry of Labour and Social Security, the only 11,96 \% of 12 million 663 thousand 783 registered workers is unionised. The number of unionised workers by increasing to 5.95 percent compared to the previous period has reached to 1,514,053 in Turkey (ÇSGB, 2016a). In Turkey, the labour unions are organised under the umbrella of three different confederations named TÜRK-iş, DiSK, and HAK-iş. According to last data of 2016, TÜRK-iş the largest confederation with 58 per cent of the unionised workers, HAK-iş is the second confederation with 29 percent, and DiSK is the third with 10 per cent (sendika.org, 2016). KESK is one of three confederations covering civil servants, and it has 221.069 civil servant members and 7.9 percent rate of total membership (ÇSGB, 2016b). Mello (2010, p.2) also emphasised that Turkish Labor Movement is based on three main factors: first, the notion that the state granted labor rights and freedoms without a protracted struggle from below, second, the notion that the military coup of 1980 effectively crushed the Turkish labor movement, and finally, the belief that the Turkish labor movement became hampered by internal divisions resulting from abstract theoretical debates.

Moore (2011) questioned whether class identity can be replaced with other elements of consciousness and found the strong evidence on incomplete forms of consciousness among young workers and how the cultural identity forms shape the labour activism. She (2011) also argued that while there is broadly a class conception of society, class was often defined by money or lifestyle rather than politically or ideologically and arising from this, there is some confusion about working class identity. Since particular social, economic and political conditions shape consciousness it is also important to acknowledge that the activism of previous generations of trade unionists was also constrained by the conservatism and sectionalism of the prevailing ideologies and languages of Labourism, in particular, an exclusionary language that reflected divisions of labour based on gender and race and subordinated these to class. It is possible that the language of neoliberalism has reversed this subordination in its attempt to dissipate collective categories ideologically through the assertion of individualised identity based upon the market.

\section{Methodology and Findings}

I have examined "Sendika.Org" as the voice of labour movement and the websites of two important labour unions, The Confederation of Public Employees' Trade Unions (KESK) and Confederation of Revolutionary Workers' Unions (DISK), to reveal their potentials in triggering the labour movement and the class-based discussions. This study has focused on the usage of the Internet by the activist groups, including the local 
extension of the international activist organizations and analyzed the utilization and outcomes of web-based activism. This study has combined the qualitative and quantitative methods. Firstly, the content analysis of the organisations' websites has illustrated their performance and functions concerning activism. The content analysis categories (e.g. information provision, networking, participation, campaigning, and delivery) have been constituted by using the model developed by Kavada (2005). Secondly, the qualitative analysis has been performed to evaluate whether the activist websites are 'participatory-beneficial'.

The characteristics of the websites such as information, actual mobilization, interactivity and userfriendliness have been analysed. The analysis has been based on the categories such as feedback opportunities, electronic correspondence, online debates, action calendar, personal contribution, links with the social media, and online activities. Given that a particular activist group is capable of using the Internet to achieve their group objectives, I have explored whether this correlated with online collective political actions. Moreover, since online activism can develop participatory democracy and create a public sphere, I have focused on this aspect of online activism.

Confederation of Revolutionary Workers' Unions (DISK) was founded in 1967. DiSK is affiliated with the International Trade Union Confederation, and the European Trade Union Confederation. DISK is a democratic organisation combining workers and struggles not only for workers' workplace issues but also being their voices in society (disk.org.tr, 2016). The Confederation of Public Employees' Trade Unions (KESK) is one of the four major national trade union centres in Turkey. It was formed in 1995. KESK defends the right to the political organisation of all labour world, is independent from the government and capital groups and supports the labour struggles (kesk.org, 2016). Sendika.org is a common ground of struggle for the working class, the oppressed social communities, and academics in a large segment. Also, it is a platform providing information for labour circles such as news reports on labour issues, forum pages, main texts concerning workers' rights, and legal support via the Internet. It encourages readers to get actively involved in strikes, resistance and solidarity campaigns as an activist media platform (Sendika.org, 2016).

The content analysis categories have been based on the method developed by Kavada (2005). The content analysis has been performed within the frame of reference of some categories like information provision, networking, participation, campaigning, and delivery.

Table 1. Information provision

\begin{tabular}{|c|c|c|c|}
\hline & DISK & KESK & SENDIKA.ORG \\
\hline Organizational history & $\checkmark$ & $\checkmark$ & $\checkmark$ \\
\hline Structure & $\checkmark$ & $\checkmark$ & - \\
\hline Values/ideology & $\boldsymbol{V}$ & $\checkmark$ & $\boldsymbol{V}$ \\
\hline Policies & 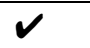 & $\checkmark$ & $\nu$ \\
\hline Documents & $\checkmark$ & $\checkmark$ & $\checkmark$ \\
\hline Newsletters & - & $\checkmark$ & $\checkmark$ \\
\hline Media releases & $\checkmark$ & $\checkmark$ & $\checkmark$ \\
\hline
\end{tabular}




\begin{tabular}{|l|l|l|l|}
\hline & & & \\
\hline People/who's who & $\boldsymbol{V}$ & $\boldsymbol{V}$ & - \\
\hline Event calendar asked & - & $\boldsymbol{V}$ & $\boldsymbol{V}$ \\
\hline $\begin{array}{l}\text { Frequently } \\
\text { questions }\end{array}$ & - & - & - \\
\hline Privacy policy & - & - & $\boldsymbol{V}$ \\
\hline $\begin{array}{l}\text { Article archive or } \\
\text { library }\end{array}$ & $\boldsymbol{V}$ & $\boldsymbol{V}$ & $\boldsymbol{V}$ \\
\hline News about & $\boldsymbol{V}$ & $\boldsymbol{V}$ & - \\
\hline Work opportunities & - & - & - \\
\hline Annual report & - & - & $\boldsymbol{V}$ \\
\hline Campaigns information & $\boldsymbol{V}$ & $\boldsymbol{V}$ & $\boldsymbol{V}$ \\
\hline $\begin{array}{l}\text { Information } \\
\text { successes }\end{array}$ & $\boldsymbol{V}$ & \\
\hline
\end{tabular}

These findings have indicated the capacity of the Websites, its goals and mission, successes, history and structure. Although the Websites appeared to be adequate regarding general information on goals, campaigns, newsletters, some aspects, such as the annual report, work opportunities, and frequently asked questions, were lacking. The design of the Websites is important for communicating ideas with existing supporters and for gaining new ones. Furthermore, it can help to attract the attention of journalists and online audiences. While the website of DISK has a stagnant appearance than others, Sendika.org has a rich and dynamic content related to developments on labour issues.

Table 2. Networking

\begin{tabular}{|l|l|l|l|}
\hline & DISK & KESK & SENDIKA.ORG \\
\hline Internal links & $\boldsymbol{V}$ & $\boldsymbol{}$ & \\
\hline Members-only area & - & - & - \\
\hline Partisan links & - & - & - \\
\hline Reference links & $\boldsymbol{V}$ & $\checkmark$ & $\checkmark$ \\
\hline Commercial links & - & - & - \\
\hline Opponent links & - & - & - \\
\hline Social media links & - & $\checkmark$ & $\checkmark$ \\
\end{tabular}

The links of a website demonstrate the information flow with other networks. It means diversity of target audience, campaign, and project, and enhance cooperation between different groups. These websites contain connections with other websites, particularly, internal and reference links, which come to fore as forms of comradeship and support. As the websites are open-access, a 'members only' area does not limit it. There were no partisan, commercial or opponent links. The website of DISK has only Facebook connection. With this 
aspect, it seems weak to reach to masses due to the lack of Twitter connection.

Table 3. Participation

\begin{tabular}{|l|l|l|l|}
\hline & DISK & KESK & SENDIKA.ORG \\
\hline Openness & $\checkmark$ & $\checkmark$ & $\checkmark$ \\
\hline Feedback & $\checkmark$ & $\checkmark$ & $\checkmark$ \\
\hline Opinion polls & - & & - \\
\hline Interaction & - & - & - \\
\hline
\end{tabular}

Most websites are fairly open to the public when considering the number of e-mails sent to specific units or branches within the organisation listed on the Websites. A large number of e-mail addresses is indicative of an organisation's efforts to decentralise information provision, whereby members of the public connect directly with the appropriate person to answer their enquiries (Kavada, 2005). The sample websites do not offer interactive features such as group discussions, apart from an e-mail facility, online communication form, and social media links. These websites focusing on labour and class issues seem to benefit from the standard capacities of the Internet to increase participation and interaction. However, interactivity channels should be developed to provide better user communication and information flow.

Table 4. Campaigning

\begin{tabular}{|l|l|l|l|}
\hline & DISK & KESK & SENDIKA.ORG \\
\hline $\begin{array}{l}\text { Election site/sites for } \\
\text { specific campaigns }\end{array}$ & - & - & $\checkmark$ \\
\hline $\begin{array}{l}\text { Join an e-mail update } \\
\text { list }\end{array}$ & - & $\checkmark$ & $\checkmark$ \\
\hline $\begin{array}{l}\text { Become online } \\
\text { campaigner/send and } \\
\text { e-mail/sign an online } \\
\text { petition }\end{array}$ & - & - & $\checkmark$ \\
\hline
\end{tabular}

The websites involve basic features for online activism except for DISK. KESK and Sendika.Org provide users with the option to join an e-mail update list, and the only Sendika.Org contains a link to be an online campaigner by signing a petition. This link is related to an anti-censorship campaign. Because Sendika.org is against the political-Islamist AKP government from a left-wing perspective, they have faced with censorship many times. This solidarity campaign against censorship continues via signing an online petition, intellectuals statement and alternative mobile connection options. Moreover, when it is examined the delivery methods such as homepage design, graphic images/photos, sound video live streaming, and foreign language translations, it is seen that Sendika.Org and KESK have many attractive contents. Specifically, press releases on their activities, news on continuing strikes and resistance movements, academic resources, the translations, and the news files about specific topics like woman and child workers' issues, videos indicate its innovative capacities. Delivery applications demonstrate the attractive aspects of a campaign. Not only do they focus on labour and democracy issues in Turkey, but they also discuss social inequalities issues in different parts of the world. 
Table 5. Social Media Profile (8th July 2017)

\begin{tabular}{|c|c|c|c|}
\hline & DISK & KESK & SENDIKA.ORG \\
\hline The number of Twitter followers & 59.531 & 54.734 & 261.648 \\
The number of Tweet & 30.297 & 2918 & 242.845 \\
\hline The number of Facebook followers & 20.764 & 13.954 & 109.095 \\
The number of Facebook likes & 21.073 & 13.810 & 110.617 \\
\hline
\end{tabular}

The number of the followers and sharings indicate the boundaries of a counter-public sphere consisting of leftist social groups. This space seems very narrow when considered around Turkey. Although the website is inactive and with weak content, DISK is more active than KESK in social media. On the other hand, Sendika.Org which is class-based alternative media has a strong web content and web page attractiveness and is a dynamic activist platform. In general, all these websites and social media accounts have not only messages and sharings about labour and class-based issues, but they have also contents related to democracy issues and current political discussions in Turkey. Therefore, while having a capacity to struggle against class-based inequalities, it is not easy to say that these organisations can influence or transform established mainstream political thought. When two social media platforms, Twitter and Facebook, compared to the aspects of capacity and dynamism, it is seen that both the labour unions and labour-based alternative media use Twitter more actively than Facebook. In the framework of this study, Twitter comprises more active public discussions on working class-related issues than Facebook.

\section{Conclusion}

The Internet is pivotal to new global activism, to a far greater extent than simply reducing communication costs, or transcending the geographical and temporal barriers of other communication media. Various uses of the Internet and other digital media facilitate loosely structured networks, strengthen weak identity ties, and promote a whole range of issues and actions that help to define new global politics. Distributed electronic public spheres have become a model for the propagation of public information in many areas of politics. The growth of global protest networks aims to bring about social justice in the neoliberal world economic regime. These activist networks have used this new digital medium to coordinate activities, plan protests, and often publicize high-quality information about their causes. The global activist networks also challenge the power of mass media (Bennett, 2003, 2004).

Mobilising participation is a crucial function of online activism. It aims to move to action those already within the movement or to motivate the general public to become involved. Despite its potential, however, the Internet has not yet been used to constitute radically new forms of protest (Pickerill, 2001). The democratic nature of digital and social media is allowing the CSOs to play a much more role in sparking people's interest in class-based issues. Public deliberations are encouraged on the Websites of these civil communities. The Internet is an alternative arena providing a new public sphere relevant to the protection of labour rights and the development of anti-capitalist policies. The online activism of labour movement communities provides a new forum for opposition to government policies. As online activist movements and their linked organisations and groups have no legal basis to influence political actors directly, they need to share their aims with the political public sphere. Therefore, they mobilise supporters by sharing their political agendas to create change in the political arena.

As Roberts noted (2014), new media represent modes of activism, dissent, resistance. For example, Twitter grants a platform to ordinary people to express themselves about specific political issues. New media encourage people to reflect on their everyday lives. Lindgren (2017) also indicates that Internet and social media have some capacity to create networks of resistance and digital media have potential to challenge 
traditional forms of political representation. In the context of the study, although these websites announce all strikes and try to create class-consciousness in society, it can be said that their impacts are limited to the certain circles. There are many reasons for it. Particularly, from an industrial to a post-industrial society, traditional social identities like the class have lost its social significance. Today, the decline or the transformation of the left politics forms a base for invisible of class politics. The class-consciousness is no longer a central feature of contemporary class relations. Even though it is insufficient for influencing and determining major policies, the working class-related websites have essential functions related to organizing, mobilizing, informing, and promoting debate, as well as providing an alternative medium, and a counter-public sphere where collective identities can form. The findings of the study have revealed there is a lack of online performance of the labour unions. Accordingly, social media should be utilized to create new opportunities for offline actions and to be much more visible, and the labour organizations should rebuild themselves within the online environment.

\section{References}

Anduiza, E., Cantijoch, M. \& Gallego, A. (2009). Political Participation and the Internet: A Field Essay. Information, Communication \& Society, 12(6), 860-878.

Barker, C. (2012). Cultural Studies: Theory and Practice, London: Sage.

Bennett, W.L. (2003). New Media Power: the Internet and Global Activism. In N. Couldry \& J. Curran (Eds.), Contesting Media Power: Alternative Media in a Networked World (pp.17-37). Maryland: Rowman \& Littlefield Publishing Group.

Bennett, W.L. (2004). Communicating global activism: Strengths and vulnerabilities of networked politics. In W. van de Donk, B. D.Loader, P. G.Nixon \& D.Rucht (Eds.), Cyberprotest: New Media, Citizens and Social Movements (pp.109-128). London and New York: Routledge.

Bohman, J. (2010). Expanding Dialogue: the Internet, The Public Sphere, and Prospects for Transnational Democracy (2004). In J. Gripsrud, H. Moe, A. Molander \& G. Murdock (Eds.), The Idea of the Public Sphere: A Reader (pp.247-269). Maryland: Lexington Books.

Butler, T. and Watt, P. (2007). Understanding Social Inequality, London: Sage.

Couldry, N. and Curran, J. (2003) "The Paradox of Media Power", Contesting Media Power: Alternative Media in a Networked World, Nick Couldry and James Curran (Eds.), Maryland: Rowman \& Littlefield Publishers, pp.3-16.

ÇSGB (2016a). Number of Workers and Trade Union Members, http://www.csgb.gov.tr/home/contents/istatistikler/iscisendikauyesayilari/, Accessed date: July 15, 2016.

ÇSGB (2016b). Number of Members of the Public Servants' Trade Unions, July 2016, accessed date: July 22, 2016.

Dahlberg, L. (2001). the Internet and Democratic Discourse: Exploring the prospects of online deliberative forums extending the public sphere, Information, Communication \& Society, 4:4, 615-633, doi: $10.1080 / 13691180110097030$

Dahlgren, P. (2004). Foreword. In W. van de Donk, B. D. Loader, P. G.Nixon \& D. Rucht (Eds.), Cyberprotest: New media, citizens and social movements (pp.ix-xiii). London and New York: Routledge.

Dencik, L. and Wilkin, P. (2015). Worker Resistance and Media: Challenging Global Corporate Power in the 21st Century, New York: Peter Lang.

DiSK (2016). http://disk.org.tr/hakkimizda/, (Accessed date: July 23, 2016).

Dogan, M. G. (2010). When Neoliberalism Confronts the Moral Economy of Workers: The Final Spring of Turkish Labor Unions, European Journal of Turkish Studies [Online], 11 | 2010, Online since 21 October 2010, Connection on 13 June 2016. URL : http://ejts.revues.org/4321

Downey, J. and Fenton, N. (2007). Global Capital, Local Resistance? Trade Unions, National Newspapers and the Symbolic Contestation of 'Offshoring' in the UK, Current Sociology, Vol. 55(5): 651-673, DOI: 
$10.1177 / 0011392107079921$

Economist (2015). Why trade unions are declining, Sep 28th 2015, http://www.economist.com/blogs/economist-explains/2015/09/economist-explains-19, accessed date: July 17, 2016.

Feenberg, A. (2014). Great Refusal or Long March: How to Think About the Internet. In C. Fuchs \& M. Sandoval (Eds.), Critique, Social Media and the Information Society (pp. 109-124). New York: Routledge.

Fenton, N. (2007). Contesting global capital, new media, solidarity, and the role of a social imaginary. Reclaiming the Media: Communication rights and democratic media roles. In Bart Cammaerts and Nico Carpentier (eds.). Bristol and Chicago: Intellect Books.

Fuchs, C. (2008). Internet and Society: Social Theory in the Information Age. New York: Routledge.

Harlow, S. \& Harp, D. (2012). Collective Action on the Web: A cross-cultural study of social networking sites and online and offline activism in the United States and Latin America. Information, Communication \& Society, 15:2, 196-216, doi: 10.1080/1369118X.2011.591411

İnal, Kemal and Akkaymak, Güliz. (Edited by). 2012. Neoliberal Transformation of Education in Turkey. [Online] Available at: http://www.palgraveconnect.com/pc/doifinder/10.1057/9781137097811, (Accessed date: July 7 2016).

Kavada, A. (2005). Civil Society Organisations and the Internet: The Case of Amnesty International, Oxfam and the World Development Movement. In Wilma de Jong, Martin Shaw and Neil Stammers (Eds.), Global Activism, Global Media (pp.208-222). London: Pluto Press.

Kende, A. (2016). Separating Social Science Research on Activism from Social Science as Activism, Journal of Social Issues, Vol. 72, No. 2, 2016, pp. 399-412, doi: 10.1111/josi.12172

KESK (2016). http://www.kesk.org.tr/business/, (Accessed date: July 23, 2016).

Lindgren, S. (2017). Digital Media \& Society. London: Sage.

McCaughey, M. and Ayers, M.D. (Eds.) (2003). Cyberactivism: Online Activism in Theory and Practice, New York: Routledge.

Mello, B. (2010). (Re)Considering the Labor Movement in Turkey, European Journal of Turkish Studies [Online], 11 | 2010, Online since 20 October 2010, Connection on 01 July 2016. URL : http://ejts.revues.org/4305

Milan, S. and Hintz, A. (2013). Networked Collective Action and the Institutionalized Policy Debate: Bringing Cyberactivism to the Policy Arena?, Policy Studies Organization, Policy and Internet, 5:1, pp. 7-26.

Moore, S. (2011). New Trade Union Activism: Class Consciousness or Social Identity?, Hampshire: Palgrave Macmillan.

Önder, N. (2016). The Economic Transformation of Turkey: Neoliberalism and State Intervention, London and New York: I.B.Tauris.

Pickerill, J. (2001). Environmental Internet Activism in Britain. Peace Review: A Journal of Social Justice, 13(3), 365-370, doi: 10.1080/13668800120079063

Roberts, J.M. (2014). New Media and Public Activism: Neoliberalism, the State and Radical Protest in the Public Sphere. Bristol: Policy Press.

Rohlinger D.A., Bunnage L.A., Klein J. (2014) Virtual Power Plays: Social Movements, Internet Communication Technology, and Political Parties. In: Grofman B., Trechsel A., Franklin M. (eds). The Internet and Democracy in Global Perspective. Studies in Public Choice, vol 31. Springer, Cham.

Sawchuk, P.H. (2003). Studies ]in Continuing Education, Vol. 25, No. 2, pp. 163-183, DOI: 10.1080/0158037032000131510

Sendika.org (2016). http://sendika10.org/hakkimizda/, accessed date: July 23, 2016.

Tatarchevskiy, T. (2011). The 'popular' culture of Internet activism. New Media \& Society, 13(2), 297-313, doi: $10.1177 / 1461444810372785$ 
Van Laer, J. and Van Aelst, P. (2010). INTERNET AND SOCIAL MOVEMENT ACTION REPERTOIRES: Opportunities and limitations, Information, Communication \& SocietyVolume 13, Number 8, December 2010, pp. 11461171.

Vegh, S. (2003). Classifying Forms of Online Activism: The Case of Cyberprotests against the World Bank, In Martha McCaughey \& Michael D. Ayers (eds.), Cyberactivism: Online Activism in Theory and Practice, New York: Routledge.

Waltz, M. (2005). Alternative and Activist Media. Edinburgh: Edinburgh University Press.

Zhang, N. (2014). Web-based backpacking communities and online activism in China: Movement without marching, China Information, Vol. 28(2), pp. 276-296, DOI: 10.1177/0920203X14538384 